Revue d'études américaines. American Studies Journal

\title{
Travels, Translations and Limitations: Ambasciatrice Caroline Crane Marsh
}

\section{Etta Madden}

\section{(2) OpenEdition}

\section{Journals}

Electronic version

URL: https://journals.openedition.org/transatlantica/12574

DOI: 10.4000/transatlantica. 12574

ISSN: 1765-2766

\section{Publisher}

Association française d'Etudes Américaines (AFEA)

Electronic reference

Etta Madden, "Travels, Translations and Limitations: Ambasciatrice Caroline Crane Marsh ",

Transatlantica [Online], 1 | 2018, Online since 16 September 2019, connection on 31 January 2023

URL: http://journals.openedition.org/transatlantica/12574 ; DOI: https://doi.org/10.4000/ transatlantica. 12574

This text was automatically generated on 31 January 2023.

\section{(c) (i) (9)}

Creative Commons - Attribution-NonCommercial-NoDerivatives 4.0 International - CC BY-NC-ND 4.0 https://creativecommons.org/licenses/by-nc-nd/4.0/ 


\title{
Travels, Translations and Limitations: Ambasciatrice Caroline Crane Marsh
}

\author{
Etta Madden
}

The child who translates gradually perceives everything in the language of man [...] a kind of knowledge without which he would be confined all his life to the circle of his own nation-a circle

that is narrow, like everything exclusive.

Germaine de Staël, 1816

Translation forces us into new trains of thought, demanding new forms of phrase; lifts us out of the rut [...].

George Perkins Marsh, 1860

Caroline Crane Marsh (1816-1901), little known except in relationship to her husband, George Perkins Marsh, was a significant figure in her own right. Although George is notable for his involvement with establishing the Smithsonian Institution, for being an early conservationist, and for his longstanding service as a U.S. diplomat (Lowenthal 91, 251, 359), Caroline did more than prop George up in his career. To date, the longest publication dedicated to Caroline is a translated abridged version of the expansive journals she kept while the couple lived in and near Turin, the first parliamentary seat and capital of the new Italian kingdom (Lowenthal and Quartermaine). Within the title of that publication, the term ambasciatrice signals a point of this essay. While literally the translated Italian word for a female ambassador, it also translates as assistant to the male ambassador and resonates with the diminutive form also designating a lesser gender. Similar to the English "authoress" or "actress," terms used frequently in the nineteenth century but out of favor now, Italian employs such endings to designate female subjects (autrice, attrice, scrittrice, direttrice - author, actress, writer, and director, respectively). Ambasciatrice in this essay's title underscores that Caroline has been viewed primarily as an auxiliary to George in his political roles abroad, yet at the 
same time the essay revises that image by pointing to numerous other facets of her identity and developing agency. ${ }^{1}$

During a period of more than thirty years, Caroline interacted with people of other cultures during travels and cross-cultural experiences that her husband's career facilitated, first during his appointment to Constantinople (1850-53) and then in the newly formed Kingdom of Italy (1861-82). ${ }^{2}$ Caroline saw herself not only as dutiful wife to George, who supported her literary labors; but also as surrogate mother to stepson, nieces, nephews and orphans (several visited and lived with the Marshes in Italy); as social activist and teacher, for nieces and children of an orphanage and school in Florence; and as aspiring author. Her increasing self-understanding of her abilities-as well as her limitations-in all these roles were influenced by travels abroad and the published and extemporaneous translations associated with those travels. Most importantly, I assert here, Caroline's translating labors illustrate the ways in which they were more than what might be seen as the lesser-valued work of an invisible "handmaiden" to authorship; instead they should be understood as linguistic engagement that translation theorists such as Lawrence Venuti and Sherry Simon have noted is a significant part of an ethical participation in political change-for better and for worse (Venuti 19; Simon 2).

3 Caroline's language study and translating practices, which began when she was a young student in Providence, Rhode Island, in the 1820s, continued as a teacher there and in Burlington, Vermont, and New York's lower Manhattan in the 1830s. Her early skills with French, German and Latin would later contribute to studies of Italian, Turkish, Swedish and Greek ([Crane] 5, 32, 82). Early on Caroline's reading, speaking and writing other languages contributed to her knowledge of a much larger world than New England offered her. Of course, her husband's skills, interests and opportunities contributed to her development as well. Sixteen years younger than the widowed attorney she married, Caroline was drawn to George's interest in languages, culture, history and the natural sciences (Quartermaine, 1999 61). Likewise, for George, Caroline's "intellect and personal charm" had attracted and stimulated him when they met in 1839 ([Crane] 6). The couple's devotion to and dependence upon each other in their daily lives and linguistic work emerges in the written records. In fact, due to Caroline's poor eyesight, George (or another family member) often would read to or write for her (Lowenthal 91). Caroline wrote George's first biography. And they worked closely together on many literary works, including the two translated volumes that bear Caroline's name on the title page: The Hallig or, the Sheepfold in the Waters: a Tale of Humble Life on the Coast of Schleswig (1856), and The Wolfe of the Knoll, and other Poems (1859). The latter volume concludes with an ode dedicated to her "Beloved" (324-327). ${ }^{3}$ In it Caroline wrote admiringly of George as "teacher," whose "beloved voice" shared "many a sage's, many a nation's lore," and had given her "culture," even while it "charmed" her "ear."

4 This essay adds two points to prior interpretations of the relationship: first, an extension of biographer David Lowenthal's view, which includes a description of George's writings on language and translation as asserting an ever-present and proud “Anglophiliac" position (208). Caroline's writing and translating, I would add, often reveals her understanding of the process of cultural negotiation. These negotiations helped her to realize ever-present cultural differences and her own limitations in bridging or eliminating them through her belief in human "universals," even while she 
continued to long for peaceful interactions. In spite of what Venuti refers to as the inevitable "violence of translation," Caroline's hopes were to transport or "carry over" aspects of other cultures without "domesticating" the "foreign" (2008 13-20). Second, the couple's correspondence during the periods of Caroline's intense translating labors for publication demonstrates her role as more than a "handmaiden," as her selfassertion and George's dependence upon and faith in her emerge. He wrote to her, for example, when she was in the midst of the first lengthy project, laboring to complete eight pages per day, "Your translation is so good, that I almost wish you would undertake Kalevala, but that would not pay" (April 2, 1856). Kalevala, a Scandinavian epic Henry Wadsworth Longfellow had drawn from for The Song of Hiawatha (Calhoun 205), stood in the Marshes' minds. (The Harvard bard's immensely popular and financially successful epic of native American culture had appeared in 1855, just before Caroline began The Hallig.) George's letter shows his hope for Caroline as translator was not simply improvement of American readers through enlarging their global perspectives but also financial gain in a period of struggle between his appointments. While she knew they needed money, Caroline's views of translation's values also extended beyond the monetary and endured for years beyond George's attention.

These views of Caroline come to light first through consideration of The Hallig and The Wolfe of the Knoll, translated from German, Swedish and French, while the couple was stateside between George's two appointments. Then, journal records and letters referring to Caroline's numerous "extemporaneous translations" in Italy reveal her recognitions of the possibilities for, challenges of, and limitations to resolving difference. In sum, Caroline's literary works provide windows to the ongoing intertwined values of translation as an activity of cultural exchange that, at best, highlights difference and limitations even while pointing to human "universal" connections across time and space.

\section{"Nibbling at Turkish": Purposes of Translation}

Caroline's time abroad during her husband's first appointment, 1850-54, introduced her to the cultures of the Mediterranean region and eastern Europe and prompted her published translations. As the New York Tribune announcement of Wolfe of the Knoll noted, "the authoress (Mrs. Marsh) turns to good account the experience derived during the Eastern mission of her husband" (November 5, 1859). Her travels through Europe en route to Constantinople, a few holiday excursions from the post, and the return trip provided views of northern and southern Europe as well as travel south into Egypt that opened her to new ways of thinking about cross-cultural contact. While in Turkey, for example, she witnessed Anglo Protestant missionaries' attempts at social activism in the Muslim culture-trying to convert them to a Christian creed-and commented negatively upon their work, although she considered them "very nice people" ([Crane] 22). She began "nibbling at Turkish" so that she could converse with local women ([Crane] 32), presumably in a manner different from the missionaries. While there she "became much interested in the political refugees" from central Europe ([Crane] 37), including Lojus "Louis" Kossuth and Cristina Trivulsio Belgiojoso. Kossuth had been a political leader of Hungary and spokesperson for freedom of the press and democracy at the time of the European revolutions of 1848, and Belgiojoso was a noblewoman from the Lombardy region of Italy who had established a salon in 
Paris before becoming a supporter of attempts to overthrow Austria in the same revolutionary period. Both had fled to Turkey, where Belgiojoso continued her journalistic writings, including messages on the oppressive condition of women. Caroline's reflections from Constantinople capture her openness to the world around her, her attempts to engage with its political and social concerns, and her desires to do what she might to improve people's conditions, just as American correspondent Margaret Fuller had in her Tribune dispatches a few years earlier. ${ }^{4}$ Certainly, Caroline possessed a strong belief in democracy and representative government, a version of American exceptionalism that would remain with her at least in residual form, even as these cosmopolitan interchanges began to feed her reform efforts and shift her ethnocentric views.

Not long after meeting Belgiojoso, in the winter of 1853, Caroline met another woman whose writings and social reform efforts likely influenced her: Elizabeth Barrett Browning. Caroline noted that she knew Elizabeth's poetry far better than Robert's (which she knew only "a little" ([Crane] 38). ${ }^{5}$ Casa Guidi Windows, which had appeared just two years before Caroline met Elizabeth at Casa Guidi in Florence, reflects on the thronging masses supporting Italian unification-of primary interest to the Marshes. "The Cry of the Children," published a decade earlier in Blackwood's Magazine, is said to have influenced child labor reform movements. Caroline's meeting with Elizabeth stimulated later correspondence and invitations for further visits ([Crane] 38-42). Soon after meeting the poet, Caroline returned to the U.S. and began translating her two volumes, which included poetry. And in the same period, at least two of her poems, "Frustra Laboravi" and "Life's Lesson," were published. These works reveal the ways in which cross-cultural connections likely motivated her to develop her literary life as both translator and author. Even if early on she saw herself as a "handmaiden," serving what she believed the more worthy endeavors of authors she translated, Caroline's literary choices indicate she began to see herself as an agent promoting social change.

This view of translation's purposes appears in recent theoretical discussions as well as nineteenth-century publications on the topic. Caroline's translating decisions exemplify, for example, not only what Venuti refers to as "foreignizing" but also two among what Luise Von Flotow categorizes as "practices of feminist translation," all of which make the translator's work obvious, rather than "invisible": first, "supplementing," an obvious "foregrounding" or "compensation" that appears even as a kind of "textual exhibitionism," and second, "prefacing and footnoting" (Venuti 15; Von Flotow 69, qtd. in Simon 14-15). While Caroline's choices do not point to her feminist stance, they do call attention to her role as translator and to a thematic underscoring of the "foreign" even while she contrasts it with Anglo-American ways of understanding. They create a tension between maintaining particulars of "the foreign" and the "domestication" of the foreign into an assumed "transcendental" and "universal" essence. These two poles, the subject of Colleen Glenney Boggs's discussion of nineteenth-century American translating practices among authors such as Longfellow, Ralph Waldo Emerson, and Fuller, emerge in Caroline's practices and in her husband's writings about translation (Boggs 1-28).

Some of these nineteenth-century ideas George voiced in lectures during the winter of 1858-59 at Columbia in New York, later published as Lectures on the English Language (1860). Because Caroline and George shared thoughts about what they were reading and writing, it is not difficult to imagine that ideas from George's "Translation" essay in 
that collection would have influenced Caroline's thinking on the subject. In the essay George wrote that translation "forces us into new trains of thought, demanding new forms of phrase; [it] lifts us out of the rut" $(1860,616)$. Additionally, related to the concept of newness, George referred to "extemporaneous translation," "reading off into English a book or a newspaper in a foreign language." This type of translation would have engaged Caroline constantly while she lived abroad, since daily demands with letters to local political figures, responses to invitations, and reading newspapers occupied much of her time. This "extemporaneous translation," George explained, "confers the power of readily calling up familiar or less habitual words and combinations," in the process "securing us against contracting a restricted personal dialect, [...] which reacts injuriously on our own originality and variety of thought" (616).

George's ideas about translation providing "newness" and opening up a "variety of thought" echoed in many ways Germaine de Staël's, who likewise emphasized the role of translating for broadening a child's knowledge beyond "his own nation-a circle that is narrow" and "exclusive" (301). Many versions of de Staël's writings, such as the French edition of her most famous work on language-On Germany (De L'Allemagne, $4^{\text {th }}$ ed. Paris, 1818) - , T. John Paul Richter's Review of Madame de Staël's Allemagne, Corinne and Pensées et Lettres, were in the Marsh library (Catalogue 642). Collectively these volumes suggest the Marshes' familiarity with de Staël's ideas. Language study, she explained, "combines precision of reason with independence of thought" (301). She connected geographical region to language, and language to national character. She wrote, "By studying the spirit and character of a language, one comes to know the historical cause of national opinions, customs, and usages" (289). In her eyes, this integral connection of language with "a particular culture" and "national character" lay at the heart of translation work. De Staël saw the translator's work as "negotiating universality through particularity" (Boggs 95). The "universal" would be the tool that would "do good for the human race" ("The Spirit of Translations" 1816, qtd. in Boggs 95). Yet the translator must also maintain a sense of the particular.

11 George extended some of her ideas by linking a culture's language to its moral life: "every nation forms a vocabulary suited to its own moral and intellectual character, its circumstances, habits, taste and opinions, [...] not precisely adapted to the expression of the conceptions, emotions and passions of any other people" $(1860,597)$. His moral stance and what he would express as a resistance to change distinguish his view, however, as "Anglophiliac" and provide a point of contrast also to Caroline's, as they emerged in her writing. George saw English as better than "so much of the contemporary expression of Continental genius, a magic mirror showing forth the unsubstantial dreams of an idle, luxurious, and fantastic people," that had profited from its interaction with Romance languages. This "amalgamation" caused English to be better than "both Teutonic and Romance literature" (Lowenthal 208). The goal of the mix, through circulation of published texts, was promoting "'oneness of thought and oneness of speech"' (qtd. in Lowenthal 211). Caroline's linguistic work, by contrast, while attempting to recognize human connections across cultures, continually acknowledged difference, or the particularities within the universals, as Boggs has described the views of de Staël and her American follower, Fuller, gradually shedding some of the judgmental American exceptionalism she originally manifested (100). 

literary woman crossing cultures. Translating, he explained, included rewording ideas within the same language, as even "ancient rhetorical instructions advised their pupils to practise [sic]" such exercises in "paraphrase" and "metaphrase" for their educational value, and Benjamin Franklin had followed suit with Addison (614). This educational theory, not new to him, reflects methods Transcendentalist author and teacher Fuller had assigned to female students at the Greene Street School in Providence and in her Conversations with women in Boston. This philosophy of "knowledge reproduction," she explained, began with copying but moved beyond it with reflection, rendering creativity and new thought (Vogelius). Strict copying of "forms and lessons" would lead students to understand "the limitations of the copy" and prompt them to develop "personal voice" and ideas.

13 This development from strict copyist or simple decoder of language to what Boggs refers to as "literary innovation" emerges in Caroline's writings $(2007,6)$. In addition to the published translations from German, she left behind a short story modeled on children's fables she read in Italian and poetry that imitated Horace's odes in Latin and Elizabeth Barrett Browning's in English. Likewise, the title poem of Wolfe of the Knoll appears to be her own creation rather than a translation. These texts together illustrate how Caroline's experiences abroad and her translating, at both extemporaneous and literary levels, recognized and negotiated cultural differences without eliminating them.

\section{Published Translations: Handmaiden and Mediating Agent (1856-1860)}

During the stateside period, the couple was in a period of financial limbo, as George wrestled with claims for back pay he believed his due from the U.S. government. The time they spent in New York "was a therapeutic and social if not a financial success," Lowenthal has explained. Not only was Caroline's health improved, but also the city "was intellectually stimulating" (197-98). They interacted in the salon culture supported by Anne Lynch Botta, who was married to an expatriate Italian political leader and philosophy professor, Vincenzo Botta. George encouraged Caroline's translation of The Hallig, helped her negotiate with the publisher, Gould and Lincoln, and advised her on specific words and the editorial apparatus, such as the German author's biography, which he wrote, and the translator's note. Although her translations, like her husband's lectures and literary work, were financially motivated, they and letters about them also convey a didactic purpose. The next summer, 1859, they returned to Vermont, where Caroline completed Wolfe of the Knoll and George prepared his lectures for publication. The volumes were advertised and reviewed together, and the couple was "warmed by New York and Boston reviews." Caroline's work, according to the London Athenaeum (11 August 1860), "was no ordinary transatlantic drivel," or "'third-rate Germanism,' but [rather] on a par with 'our own romantic poetesses"' (qtd. in Lowenthal 200).

Lowenthal describes Caroline's Wolfe of the Knoll as "inspired by her German reading and travels in the Levant" (199-200). But the volume's contents and those of The Hallig provide a significant extension of Lowenthal's descriptions. First, the volumes' contents suggest that female literary figures such as Barrett Browning and Lynch Botta,

Transatlantica, 1 | 2018 
foremost among "the literati of New York" at mid-century (Oliva 6), influenced Caroline's interest in, and written expression of, both cross-cultural exchange and social reform. Second, they reveal Caroline's role as active, mediating agent as a translator, especially in the volumes' cross-cultural contents, including their "prefacing and footnoting." With the selections of what literary works to translate, and how to introduce them to readers, Caroline made obvious her goal of educating Americans on other cultures.

As for selecting content, publishers Gould and Lincoln had written prior to the first translation that the Marshes knew what choices to make "for the American people" (February 5, 1856). And publisher Charles Scribner wrote about Wolfe of the Knoll, in spite of the "unsalebility" [sic] of poetry, he believed it worth publishing and would do what he could to help its circulation (March 29, 1859). Caroline selected cultures beyond the typical for armchair travelers or those of privilege who have experienced the typical "Grand Tour" of Europe-over the Atlantic to England and across the channel to the continent, south and west through France, over the Alps to the Italian peninsula before return north into Bavaria. In both The Hallig and The Wolfe, Caroline made connections between the region of northern Germany known as the Schleswig and other parts of the world, such as the northern coast of Africa, whose languages, dialects and religious practices seemed much more "strange" and "foreign" than the more typically read literature of France, Germany, Spain and classical Greece and Rome.

17 While The Hallig focuses on a single area and story, The Wolfe is an anthology similar to Botta's Handbook of Universal Literature (1860), published just after Caroline's translations, in its culturally wide-ranging content. Botta's Handbook includes, for example, literature and authors of diverse cultures and traditions-Hebrew, Persian, Sanskrit, German, and Scandinavian. The anthology became a standard text for university students, in use for decades, with several revised editions. The signed gift copy of Botta's Handbook in the Marsh library also reflects the global interests of literati with whom Caroline was engaged (Catalogue 84, 412).

Both volumes demonstrate Caroline's interests in religion, as she explains in her twopage introduction to the first lengthy poem in The Wolfe, for which the volume is titled. That is, it includes much more than what the Tribune described as the long "narrative romantic poem." Many works in Wolfe, translated primarily from German and French, consider religious themes throughout Europe and northern Africa. ${ }^{6}$ Caroline selected "A Godlie Hymn" from Ulrich Zwingli as well as a "Fable" about a widow who has lost all her "little lambs" except one. In it, the woman continues to pray regularly and to send her lamb to the pasture, where it, too, is devoured by the wolf. "Daniel, the Cistercian" is based on a story illustrated on the wall of a monastery in Osseg, Bohemia, about a monk whose own obedient, faithful works light his hand and the path ahead of him. And "The Glow-Worm" from Helmine Von Chezy celebrates God's care for such small and seemingly insignificant creations. Many works intertwine religion with tales of romantic love. "The Moss-Rose," also from Von Chezy, emphasizes how beauty springs from pain and suffering. "A Lay of the Danube," for example, ends with lovers only getting to be together in eternity. Such epic and lyric verses as "Song of the Lapland Lover" from the Swedish of Franzen and "The Maid of the Merry Heart" are of the style popular with Longfellow and Tennyson, among others; regular meter and rhyme sing stories of adventure, love and loss. These themes cross cultural boundaries with 
attempts to demonstrate a "universal" suffering and human spirit even as they recognize what is "peculiar" to each region.

The "Translator's Preface" (iii-v) to The Hallig describes the work as "a highly interesting contribution to the physical geography of a part of Europe lying quite beyond the reach of ordinary observation." More than merely descriptive, the twentyfive-chapter, almost-300-page prose romance includes adventure, travel, love and loss -dramatic elements "of human life under conditions which are hardly paralleled elsewhere," all set in the Hallig, a remote island of the North Sea. The work's "skillful and picturesque delineations of nature and of man, in their reciprocal action under new and strange relations," Caroline stated, would "interest and instruct" readers. The "new and strange relations" were based on the author's experience in a new culture. The author, Johann Christoph Biernatzki (1795-1840), wove a fictional thread through his autobiographical account of the life and theology of an outsider. The outsider, a Lutheran pastor who speaks "High German," arrived from elsewhere in Germany to serve this community. Caroline's Preface refers to the pastor's complex and challenging relationship with "his flock," perhaps of interest to her because of George's work as a secular minister in a strange country and because of Protestant missionaries she witnessed in Turkey. That is, it captures an outsider's relations with insiders over an extended period of living within another culture.

The introductory comments to both volumes invite consideration of Caroline's agency, as she removes the veil of invisibility by calling attention to herself through the textual apparatus. In addition to The Hallig's "Translator's Preface," which informs readers that it is Caroline's rather than Biernatzki's introduction, in Wolfe, for example, she noted that the verses related to her experiences in other cultures, and she wanted to mediate, or "carry over" these feelings of difference through the translation. As she explained, the title epic's purpose is "to connect the strong contrasts of life and nature offered by the peculiar regions" (12, emphasis mine). It presents paired contrasts, alternating between the Baltic and the Mediterranean: "the island of Amrum near the coast of the duchy of Schleswig-Holstein, and in the city of Tunis and the territory of that Beylik" (emphasis mine).

21 Here as in other sites throughout the volume, she calls attention to a culturally-specific term. Rather than substituting "territory" or "kingdom" or defining Beylik, she pushes readers to experience the culture's term and, thus, something of its political and governing structure, even while demonstrating her own knowledge. Throughout her selections, she chose to emphasize the "new and strange relations" that the works convey. Often explanatory footnotes call attention to Caroline as translator and her desire to "supplement" with instruction from her knowledge of other cultures, especially as she saw how prior translations failed to "carry over" meanings that conveyed the appropriate differences. She wrestled with how much of this material to include in notes and what to place in appendices, wanting to acknowledge her sources. 7

These accounts illustrate cultural practices such as "the hareem" and hospitality to the stranger-points that Marsh wants to make for her Anglo-Christian readers, who likely misunderstand Muslim culture. For example, one poem includes the note, "The morning prayer of the faithful Mohammedan should commence as soon as he can distinguish a white thread from a black one." Other exemplary notes of linguistic work explain that "the invited of God" is a "name given to a stranger who asks hospitality" 
(30), or develop the historical and social significance of Khair-ad-deen's name, which means "the Excellence of Religion." Instead, he has been ineptly named as Barbarossa, the Redbeard, which does not convey the respect he is due as "Nelson" of the Ottoman empire in the sixteenth century, when he conquered Algiers and Turin and frightened the Franks, the Spaniards and the Italians (29).

Beyond the notes, specific elements of translation within both volumes mark Caroline's desire to make overt the "strange." Caroline acknowledged that Biernatzki had been influenced by "the orient" and had "a more figurative mode of expression than is quite consistent with the soberer taste of the best European writers," but she did not attempt to "retrench" his "exuberance" in her translation. Her decisions come to light alongside another English translation, Samuel Jackson's The Maid of the Hallig, which had appeared in London in $1843 .{ }^{8}$ Most obviously, Jackson inserted no didactic textual apparatus-neither a translator's note nor a biographical sketch of the author to call attention to himself as translator.

The opening paragraphs reveal how Caroline made Biernatzki's language even more figurative and intensively pejorative than the "original," while Jackson presented them more similarly, attempting what translation theorist Eugene A. Nida would later refer to as providing "functional equivalence," a seamless transition with a "naturalness of expression" from one culture to another in the transfer of meaning (Venuti 16). Personifying the powerful waters of the region, Caroline at first employed and repeated Biernatzki's phrase "trügerische Riese" (2)-"the treacherous giant" (26) rather than Jackson's slightly softer "the gigantic foe" (2). But while Biernatzki described the islands as entangled by the sea like arms of a snake-"gleichsam Schlangenarme" (2)-and Jackson used the simile, "the channels [...] wind themselves, as with snaky folds, around the islands" (1-2), Caroline contracted the simile, choosing the more powerful rhetorical device, a metaphor. She made the islands entangled in "the serpent embrace of their giant enemy" (26). Contributing to the negative language and calling attention to her position as translator, she translated the German "Wanderer" into the more pejorative "loiterer" and transliterated "Wasserwüste" (3) as "waste of waters" (26) rather than as "mud flats" or "estuary," or another term familiar to those on the U.S. east coast. For Biernatzki's Schlickgrund she referred to "slimy flats" (2) at ebb-tide, where Jackson simply chose "a muddy bed" (1), and for his Schlickläufer (3) she gives ebb-walker, leaving it italicized to highlight the strangeness of this word and character to U.S. culture. Jackson simply had "the sand-stroller," with no visual indicator such as italics (2). ${ }^{9}$

A few additional specific choices within The Hallig and "The Wolfe of the Knoll" will illustrate Caroline's attention to "the peculiar." For example, Caroline must have asked George about the meaning of the Hallig hero Godber's name and whether to use Gottber -the high German "bright God"-instead, for George wrote to her in early January, 1856, "Godber is closer to our idiomatic forms than Gottber." She responded in her next letter, "Why will not the name Godber then do just as it is?" And the more "idiomatic" remained. The correspondence reflects Caroline's desire to capture the regional, low German form rather than the high German, which might have been more recognizable to English readers and certainly would have reflected the growing nineteenth-century desires for national languages. Similarly, Caroline queried George by letter in August 1859 about two phrases she wished to employ as identifiers for the main characters of "Wolfe of the Knoll." Would "Iceland Bride" and "Wonder Child" be "too foreign?" The 
decision was to maintain these particular labels of difference within the publication $(82,88)$.

Caroline's translating decisions-at the micro-level of phrases and the macro-level of including specific literary selections and textual apparatus-demonstrate both the regional particularities and the global networks of the many who had sailed and continued to traverse the seas, from the Baltic, through the Atlantic, into the Mediterranean and beyond. The topic remained of interest to Caroline during her second and longer period abroad. In the newly unified Kingdom of Italy, she again would seize opportunities to interact with those around her, reading their regional literature and attempting to understand and participate in the culture as an effective mediator.

\section{Extemporaneous Translations: The Idea of Italy, Revised}

When Caroline arrived in Turin in 1861, she brought with her not only her translating skills and past experiences abroad but a pre-established view of Italy's oppressive subjugation to other European powers and the Roman Catholic church. She and other American Protestants were celebrating the religious liberty non-Roman Catholics in the Piedmont region had been enjoying since 1848, ushered in by European revolutions (Mortara 57). For her as for many Americans who observed the political changes from afar, "Italy" provided a playground for enacting what they believed were the best America offered as model: democratic leadership, accessible education for the masses and, through these two venues, alleviation of poverty (Vance 94; Gemme). This idea of "Italy" and its possible futures shifted for Caroline as she, who labeled herself a "Progressivist," religiously speaking, continuously gained new information about the culture in which she lived. ${ }^{10}$ Many journal pages reveal Caroline being moved by a thread of human sympathy that tugged at her heart. Lowenthal emphasizes what he sees as Caroline's transformation from "moralist" to "informant as participant sociologist" in Italy, describing "her rigidly egalitarian rustic New England Puritanism" giving way in the face of "everyday life," where "she became less critical and more compassionate, less censorious and more self-deprecating." (2008 157-58). I would add that while she maintained her American Protestant "Progressivist" stance, several journal entries reveal Caroline was beginning to let go of her ideals about missions and social reform-and these changes emerged through extemporaneous and private, rather than published, translations.

Soon after the Marshes' arrival in the Piedmont, for example, Caroline met "Mr. Bert," a leader of the non-Catholic Waldensians, and was impressed by his knowledge of many languages (9). ${ }^{11}$ The next day she wrote of parliament at Turin discussing the kidnapping of Jewish babies and other "evil" works of the Roman Catholic priests, "a story too scandalous to be believed," she explained, except "for the evasions" of those testifying, which gave the stories "substance" (21). But by 1863 any simple antiCatholic/pro-Catholic binary was confounded in her journal. She expressed frustration about political leaders, such as their friends Vincenzo Botta and Massimo d'Azeglio, writing that such men changed their minds about politics and philosophy, but about religion they never did. Even when educated-that is, knowledgeable of other languages and cultures-they hung onto "superstitions" from their childhood (164). But 
she also negatively critiqued one of Waldensian Bert's colleagues, Meille, for a funeral oration he delivered. He did not understand that taking the public opportunity to make negative comments about Roman Catholics to an audience of primarily Roman Catholics was not persuasive rhetoric nor the best practice for realizing religious reform (173). ${ }^{12}$

Other entries during a period when the Marshes had undergone a somewhat isolating move to a rural area on the plains of the Po southwest of Turin demonstrate Caroline's changed household management, relationships and cultural views. The change decreased urban visitors while it increased reading and writing time and opportunities for interactions, or influential "extemporaneous translations" with the gardener's family. When the village priest arrived to bless the Marshes' new home, for example, Caroline did not pay him to perform the rite which, for her, had no efficacy. She did, however, communicate with and pay the priest to bless the gardener's house (166). ${ }^{13} \mathrm{~A}$ month later she swapped tales with the gardener's wife. When Caroline confessed sadness due to missing family, her new confidant expressed surprise that even the Marshes, with their material abundance, felt the pain of personal loss (176). ${ }^{14}$

30 A third reference to the influential extemporaneous translations with the gardener's family arose from Caroline's reading. She wrote of "a little anthology of Italian tales" (174)-likely Temistocle Gradi's Racconti popolari, which was in the Marsh library (Catalogue 286). ${ }^{15}$ She explained that all three tales that she read underscored challenges of village life. Two elements of Caroline's response to this translating work merit noting. First, she transcribed into her journal rhyming lines of proverbs from the book without translating them. That is, some she paraphrased in English, and others she copied in the original language, suggesting she wanted to remember the latter to use as needed. Also, they reflect her understanding of the particular area. For example, of one story she explained: "The writer, in speaking of the inhabitants who according to him are not very kind and honest, he admits that they have had for centuries a bad reputation and, as proposed by Radda, cited this proverb: Radda!/Passa e guarda!/Non ti fermar per via,/Chi 'un ${ }^{*}$ fa 'l ladro, fa la spia." 16 The entry continues with a description and transcription of "the third story," which is "a legend of the same region." She explains, "the writer takes occasion, after painting the horrors of life here during the Middle Ages, to pay Baron Ricasoli a handsome compliment." The Baron, known as the "terrible Brolio" who ruled forcefully and cruelly, no longer reigns. The old rhyme "Quando Brolio vuol broliare/ Tutta Siena fa tremare!" no longer carries much value, as the family leadership has been supportive of national unification. ${ }^{17}$ Both tales point to regional isolation and reign, maintained through fear and warfare, even as Caroline recognizes that times are changing.

31 Perhaps Caroline wanted to practice recall of such proverbs central to the culture. Perhaps she was considering another publication, similar to Wolfe but focused on Italy. Neither came to pass. But they may have prompted her drafting of an unpublished children's tale in English. An additional point worth noting is that Caroline was so moved by these tales-likely the regional particularities they revealed-that she decided to follow the gardener's advice when he saw her reading them. He recommended that the Marshes' niece Carrie, who was living with them, study Piedmont rather than Tuscan tales, because they would help her fit in to the region, and he offered to find a local teacher for her (175). ${ }^{18}$ 

Italian setting, the mountain village Pruno and its rags-to-moral riches hero. Its topics include the value of literacy, the necessities of hard work and shunning frivolous parties, the challenges of arranged marriages, the power of the domestic realm, the responsibilities of parenting-all themes that would reappear in Caroline's journal entries. ${ }^{19}$ But the tale also includes another theme-religious art as a vocation. Early on, the hero played his fiddle at dances. When he fell ill, a friar told him he "deserved it for going out to play at night-frolics." He then "broke" his fiddle and channeled his love of music into becoming the church organist. In addition to developing musically, the hero also becomes a visual artist. Enduring patience, hard work, and criticism, he carved first a crucifix in wood, then with marble. He left a Madonna on a hillside, then created a Saint Michael and a "Conception," based on pictures he had seen of "a young girl with her hands clasped, a crown of twelve stars on her head and the half moon and the serpent under her feet." Next he created a St. Anthony, another Madonna, a Martha and a Magdalen. Notably, the story shows that Caroline now shunned neither Roman Catholic aesthetics nor Mariology. The hero's concluding deathbed message speaks Caroline's transformed, more inclusive view, even while it voices remnants of her New England ethic: "As to me I have always seen that he who works hard, and does all the good he can will get on somehow,--he'll get on, and never come to a bad end. God is for us all" (49). Through her translations and her interactions with individuals with unique differences, Caroline's views of religious life and her own art were evolving, slowly accepting more of other ways of being.

\section{Extemporaneous Translation: Increasing Ambivalence and Limitations}

Despite openness to some Roman Catholic practices in Italy, Caroline's writings also demonstrate initial desires for Protestant social reform and increasing ambivalence about it. While Caroline's time in the Piedmont had introduced her to European salon culture, by the late 1860s when the Marshes and the Italian capital had moved to Florence, she became engaged with reform efforts. She wrote in her journal less as she engaged more with needs around her, especially focusing on females and extending the project of political exile Salvatore Ferretti, who returned to Florence from London in 1862 as a leader of the "Free Church" movement and founder of the school which bore his name. Caroline's work became a favorite of Anglo supporters in the U.S., Scotland and England. Letters to and from prominent U.S. and British families refer to their support of it. In addition to New York philanthropist Mrs. J. J. Augusta Astor, for example, donors included Cyrus West Field, founder of the Atlantic Telegraph Company, responsible for the first transatlantic cable connected in 1858, who sent funds through Caroline's nephew Alexander B. Crane, another successful New York businessman.

Countering such records of leadership roles and fundraising successes through her letters, however, Caroline's less-frequent journal entries provide another picture. Entries from the fall of 1873, in particular, erupt with trials-with arranging teachers, with debts, and with troublesome committee members. She wrote in November, for example, while George was in Rome, "Yesterday went to a meeting of our Orphanage Com. Debts over 7000 frcs!" (Diary 6 November 1873). Three days later, she picked up 
the thread again, writing of an out-of-touch, unnamed committee member labeled merely, "Mme Blank." The woman proposed as a fundraiser one of several "private theatricals," noting that it "would be very fine-not a dress was to cost less than 1500 frc." With rough calculations of 1500 francs as about 300 dollars in 1873, the price of each dress would be exorbitant.

Simultaneous to such challenging meetings, Caroline was "translating extemporaneously" as she read works on approaches to religion and social reform. She wrote in her journal, for example, of Fénelon's assertion that "everyday acts" should have "a religious character"; of the "very suggestive" material in [James Anthony] Froude's "Philosophy of Catholicism"; and about "a curious book" by Charles de Ribbe, Les Familles et la société en France avant la Révolution, that "ought to be read by all of us Progressivists." ${ }^{20}$ The string of titles suggests more than her desire to keep up with the latest literature and ability to read French. This extemporaneous translation points to how French authors' ideas about religion intertwined with Caroline's activism, combining to manifest uncertainties, frustrations and new ideas. Would she give up her goals or keep trying? Would she hang on to old methods, infusing them with new ideas, or employ new methods but attempt to teach old "truths"? Fénelon's "everyday acts" suggests an answer-an approach to reform that would be partial and fragmentary, on an individual level, rather than one of overarching uniformity that would insist on cultural conversion or oppression in the shadow of national unity. As Fuller's writings had recognized twenty years earlier, the ideal of "national unity" enacted would do so at the risk of dissolving or overlooking the needs of unique individuals (Boggs 108). That is, Caroline's comments reflect theories of translation that indicate an openness to ideas that crossed national and cultural boundaries, a cosmopolitanism that, even as it sought universals, recognized ongoing difference.

Another example of this openness appears in Caroline's response to Matthew Arnold's Literature and Dogma entered in her journal a few weeks earlier. ${ }^{21}$ Although she did not find Arnold's ideas compelling, she read them "with infinitely more pleasure for knowing him personally." But knowing Arnold was not enough. Caroline explained that the touchstone was his openness: "[H]ow completely he possesses the spirit of a learner. [...] Instead of talking oracularly like so many litterateurs, he is evidently trying to collect new truths." Arnold appealed to her because he was "a modest listener where he might well assume to teach" (Diary, October 19, 1873). Although a teacher herself, in this period Caroline wavered in confidence about "truths" that some "litterateurs" espoused. Ironically, one such figure was Fénelon, referenced during the same period, who was well-known for his moralistic didacticism and highly popular novel Telemachus, published widely in France, England and the U.S. (Bell 54-65). Caroline's unpublished tale set in the mountain village Pruno likely was influenced by his method of teaching children through moralistic fables. But because no record indicates that the tale ever circulated, she may have doubted her writing skills, or she may have lost faith in this method's efficacy. Nonetheless, she continued to believe in extemporaneous translation as a means of crossing cultures and learning about others, rather than as a means of imposing truths.

Caroline's reading of Horace's first and second odes in Latin in this same difficult year of 1873 supports this assertion (Diary, Nov. 22, Dec. 1). The Marshes owned poetic collections of Horace's works in Latin, as well as in Italian, English, and German, and a book on his metrical style (Lundy, Metra Horatiana; Catalogue 329, 422). The themes of 
the odes range broadly from artistic skill and patriotism to love and loss and war and peace. Without specific references to the content, it is impossible to know what themes might have touched and influenced Caroline. But the journal reference underscores her ongoing translating and her love of poetry's imagery and meter which powerfully convey such themes.

\section{Predictive Poetry: "Frustra Laboravi”}

One poem Caroline wrote and published years earlier was eerily anticipatory of the despair and hope she balanced in the mid-1870s. It provides a conclusion to this essay because although it does not employ translation, it reveals her global and "universal" interests as she worked intensively with language to give shape to perhaps inchoate sensations and to publicly share those thoughts through carefully crafted verse. Published at the invitation of Abby Maria Hemenway within her anthology Poets and Poetry of Vermont (1860), the poem also celebrates female labor in many forms and is not linked to the regionalism Hemenway's title suggests. ${ }^{22}$ With the Latin title, "Frustra Laboravi," which evokes a phrase from Job 9:29, "in vain have I labored," the poem acknowledges past difficulties but refuses to give up hope, anticipating those emotions that filled Caroline's journal pages in 1873. Although no overt self-references appear in the poem, Caroline seems to have written it in a moment when waves of memories of failed idealistic ventures washed over her. Indeed, the period of composition was that of intense financial need and future uncertainties, when she labored with her translations and wrestled with family responsibilities, such as George's young adult son. This son from a first marriage remained financially dependent on his father and implicated in business problems in Vermont, where Caroline translated while George was in New York. The verses would have helped her process such experiences, just as translating Horace's poetry did. Although the poem's title suggests a religious tone, the verses include no appeal to the divine for delivery. Instead of a heavenly, spiritual or transcendental realm, it exudes a "universal" sentimental connection with humanity writ large while grounding the problems in specific allegorical examples.

of typical verse style, the poem's eight five-line stanzas each end with repetition that lends the poem hymn cadence. Variations of "I have labored in vain" serve as a refrain, emphasized with a shift from the regular iambic pentameter of the previous lines to a break with fewer feet. This broken anaphora creates not an ecstatic experience in a pleasurable sense but rather, as it is repeated through the poem, one of dulled numbness linked to grief and despair. The first stanza, in fact, opens with these feelings of pain as common to every "human" whose "voice" will exude a "bitter cry" of weariness:

"My strength is spent for nought!" This bitter cry

O'er all our earthly moanings riseth high;

For ah! No human voice shall ever fail

To swell the mighty chorus of this wail,

"I have labored in vain!" (ll. 1-5)

Following the first stanza's image of humanity in general, spent by laboring in vain, the sensations of despair continue with slight variation, as images of specific types of people who have labored in vain emerge. In the second stanza, for example, "The farmer sows in hope the golden grain," but "The torrid heavens withhold the latter rain," such that "The shriveled ear a sickly color shows,/ And the poor husbandman no 
harvest knows;/ He has labored in vain!" (ll. 6-10). The next four stanzas turn respectively to merchant, parent, artist, and reformer, all of whom have "labored in vain!" for wealth, children, art, or social change.

Although Caroline was neither farmer nor merchant, she passionately noted in her journal the poverty of Italian farmers, who ate primarily grain. While in Turin, Florence and Rome, she would have witnessed Italian merchants struggle, but the merchant's description, "with pallid cheeks" and "Dark in his brow, [as] despair doth gnaw his heart" (11. 11-12), also reflects what she wrote of her New Yorker nephew Alexander, as she saw him weaken and age under duress and encouraged him to visit Italy to relieve stress. ${ }^{23}$ And she sympathized with any parents holding a "tortured memory" of "children" who met difficult ends, "Disgraced by folly and with crime defiled" (1.17). Her stepson George fell to alcohol addiction during the Civil War and died soon after; niece Carrie died tragically when the ship Schiller sank on her travel to Italy; fragile niece Ellen died soon after leaving Caroline for the U.S.; and an adopted son Carlo remained forever unteachable, she noted in her journal. Certainly, Caroline also expressed the experience of the artist "with a strong passion stirred" who labored over "the thought [...] in [... her] soul," that often resulted in "the feeblest shadow of [...] lofty dreams" (ll. 21, 23-4). And, similar to the despairing reformer, she had attempted reform "with a noble zeal" (1. 33), while seeing "trusted weapons shattered in [her] hands" (1l. 26-27). After these variations the poem returns in its penultimate stanza from specific despairing laborers to the general situation of any "son of man" who "know[s] their highest energies misplaced,/ To have labored in vain!" (1l. 31-35).

Going further than this circuit from general to specific to general wearied laborers, however, the poem's last stanza turns to consolation through admonition. The speaker remembers, "there is a plaint more sad than this,/ Breathing of darker, deeper, hopelessness-/ 'In vain I have suffered!' (1l. 36-8). Writing of suffering, the speaker gives a directive to the "mortal" reader to "take [...] heed/ That of these fearful words thou have no need!/ Else thou has lived in vain!" (11. 38-40) Through this concluding stanza, Caroline's poem justifies the pain she has experienced-as surrogate mother, artist and reformer. She turns the poem from one focused on vanity of labors to what she sees as essential elements of life-suffering in the midst of laboring for what seems to be an important and just cause, as well as reflecting on the labor and causes to determine their justness.

The poem illustrates in brief a prediction of the many challenges Caroline would face while abroad and her adjustments to what she learned about her own limitations. Translating languages of other cultures contributed to that knowledge and a recognition of ongoing cultural differences. Yet "Frustra Laboravi"'s last stanza also crystalizes Caroline's actions in 1882, after George's death, as she prepared to rise from doubts and despair to move on with hope. More than thirty years after she had crossed the Atlantic the first time, Caroline rose to cross the Atlantic a final time. Back in the U.S. she reread her previous writings, translating them to craft her husband's biography. ${ }^{24}$ She wrote about political life, published in the New York Evening Post, and she continued to study philosophy, poetry and languages for much of her next twenty years ([Crane], 82). The experiences she had in Turkey, the translations of The Hallig and The Wolfe of the Knoll, and the numerous extemporaneous translations she noted in her journals in Italy demonstrate that for the ambasciatrice, translating was a practice 
that evoked both a connection across cultures and the inevitable limitations and gaps she realized as she faced ongoing differences.

\section{BIBLIOGRAPHY}

ARNOLD, Matthew. Literature and Dogma: An Essay Towards a Better Understanding of the Bible. London: Smith Elder, 1873.

ASTOR, Mrs. J. J. Augusta. Letter to Caroline Crane Marsh, 1868. Crane Family Papers (CFP) Box 19, Folder CRANE-Caroline \& George P. Marsh-Corres. 1868-71, New York Public Library (NYPL). BIERNATZKI, Johann C. Die Hallig, oder die Schiffbrüchigen auf dem Eiland in der Nordsee. Hammerich, Altona, 1840. reader.digitale-sammlungen.de/de/fs1/object/display/bsb10105734_00001.html (Bayerische Staatsbibliothek). Accessed April 2019.

BELL, David A. The First Total War: Napoleon's Europe and the Birth of Warfare as We Know It. New York: Houghton Mifflin, 2007.

Catalogue of the Library of George Perkins Marsh. Burlington: University of Vermont, 1892. archive.org/details/librarygeorgepero0univ. Accessed February 9, 2017.

BOGGS, Colleen G. Transnationalism and American Literature: Literary Translation 1773-1892. New York: Routledge, 2007.

CALHOUN, Charles C. Longfellow: A Rediscovered Life. Boston: Beacon Press, 2004.

CHANNING, William E. "Remarks on the Character and Writings of Fénelon." The Works of William E. Channing, D. D. vol.1. $8^{\text {th }}$ ed., Boston, J. Monroe and Company, 1848, p. 167-215. (Reprinting of "Selections from the Writings of Fénelon," The Christian Examiner, Boston, 1829).

CRANE, A. B. Letter to Caroline Crane Marsh. Jan. 21 1870, CFP, Box 19, Folder 1868-1871, NYPL.

[CRANE, Elizabeth Green]. Caroline Crane Marsh. A Life Sketch. N.p., n.d. Hathi Trust Digital Library. hdl.handle.net/2027/uc1.31175035250656. Accessed January 7, 2015.

DE RIBBE, Charles. Les familles et la société en France avant la Révolution, d'après des documents originaux. Paris: Albanel, 1873.

FIELD, Cyrus W. Letter to George P. Marsh, via A. B. Crane. March 17, 1871. CFP, Box 2 Crane-A. B. Crane-corres. 1871-1873, NYPL.

FROUDE, James A. "Philosophies of Catholicism." Short Studies on Great Subjects. London: Longman's, 1867, p. 124-132.

GEMME, Paola. Domesticating Foreign Struggles: The Italian Risorgimento and Antebellum American Identity. Athens, GA: University of Georgia Press, 2005.

GOULD and Lincoln. Letter to George Perkins Marsh. Feb. 5, 1856, GPM, Carton 2, Folder 40, George Perkins Marsh Collection (GPM), University of Vermont Library (UVM).

GRADI, Temistocle. Racconti popolari; e Rispetti politici [di Giuseppe Tigri]. Torino, 1862. 
JACKSON, Samuel. The Maid of the Hallig; or, the Unfortunate Islanders. A Narrative Founded on Fact. By the Rev. J. C. Biernatski. From the German. London: Cradock and Co., 1843. Hathi Trust Digital Library. babel.hathitrust.org/cgi/pt?id=umn.31951002122319z;view=1up;seq=9. Accessed March $10,2019$.

LOWENTHAL, David. “'The Marriage of Choice and the Marriage of Convenance': A New England Puritan Views Risorgimento Italy." Journal of Social History, vol. 42, no. 1, 2008, p. 157-174.

LOWENTHAL, David. George Perkins Marsh: Prophet of Conservation. University of Washington Press, 2000.

LOWENTHAL, David and Luisa QUARTERMAINE, eds. and introduction. Un'Americana alla corte della Savoia. Il diario dell'ambasciatrice degli Stati Uniti in Italia dal anno 1861 al 1865. Translated by Luisa Quartermaine. Torino: U. Allemandi, 2004.

LUNDY, F. J. Metra Horatiana; or the Metrical Systems of Horace, Arranged on a New Plan. Burlington, VT: C. Goodrich, 1838.

MARSH, Caroline Crane. Diary, 1863, April 8-June 14, Carton 18, Folder 14, GPM, UVM.

MARSH, Caroline Crane. Diary, Oct. 1-Dec 1 1873, Carton 18, folder 23, GPM, UVM.

MARSH, Caroline Crane. “Frustra Laboravi!” Poets and Poetry of Vermont. Ed. Abby Maria Hemenway. Revised Edition. Boston: Brown, Taggard \& Chase, 1860, p. 340-341.

MARSH, Caroline Crane. The Hallig or, the Sheepfold in the waters: a tale of humble life on the coast of Schleswig: with a biographical sketch of the author. Translated by Johann Christoph Biernatzki. Boston: Gould and Lincoln, 1856.

MARSH, Caroline Crane. Letter to A. B. Crane. January 26, 1875, CFP, Box 2, Folder 1874-75, NYPL. MARSH, Caroline Crane. Letter to A.B. Crane. Sept. 5 1875, CFP, Box 2, Folder 1874-75, NYPL.

MARSH, Caroline Crane. Letter to A.B. Crane. Dec. 19, 1876, CFP, Box 2, Folder corres.1876- JulyDec., NYPL.

MARSH, Caroline Crane. Letter to Cornelia [Crane]. Nov. 11, 1876, CFP, Box 2, Folder corres.1876July-Dec., NYPL.

MARSH, Caroline Crane. Letter to George Perkins Marsh. Jan. 9, 1856, Carton 2, Folder 40, GPM, UVM.

MARSH, Caroline Crane. Letter to George Perkins Marsh. August 12, 1859, Carton 3, Folder 34, GPM, UVM.

MARSH, Caroline Crane. Letter to George Perkins Marsh. August 1859 n.d., Carton 3, Folder 34, GPM, UVM.

MARSH, Caroline Crane. "Life's Lesson. By Mrs. Caroline Crane Marsh.” The American Journal of Education. No. XIII, June 1858, p. 29-34.

MARSH, Caroline Crane. “Story, Italian Setting.” GPM, Carton 17, Folder 36, UVM.

MARSH, Caroline Crane. Wolfe of the Knoll and other Poems. New York: Scribner, 1859. Hathi Trust Digital Library, babel.hathitrust.org/cgi/pt?id=hvd.hxdlu3;view=1up;seq=9. Accessed February 25, 2016.

MARSH, Caroline Crane, comp. Life and Letters of George Perkins Marsh. Vol. 1. New York: Charles Scribner's Sons, 1888. 
MARSH, George Perkins. Letter to Caroline Crane Marsh. Jan. 5 1856, CFP, Box 18, Folder corres. 1856-1859, NYPL.

MARSH, George Perkins. Letter to Caroline Crane Marsh. April 2, 1856, CFP, Box 18, Folder corres. 1856-1859, NYPL.

MARSH, George Perkins. "Principles of Translation." Lectures on the English Language. New York: Charles Scribner 1860, p. 596-616. Google Books. Accessed July 10, 2017.

MORTARA, Elèna. Writing for Justice: Victor Séjour, the Kidnapping of Edgardo Mortara, and the Age of Transatlantic Emancipations. Hanover: University Press of New England, 2015.

OLIVA, Justine. "The Circles of Anne C. Lynch Botta: Friendship and Power in the Nineteenth Century." Diss. University of New Hampshire, 2018.

QUARTERMAINE, Luisa. "Views from Beyond the Alps: An American in Turin: The Diary of Caroline Marsh, Wife of the First American Minister to Italy 1861-64." Marginal Voices, Marginal Forms; Diaries in European Literature and History. Eds. Rachel Langford and Russell West.

Amsterdam: Rodopi, 1999, p. 61-77.

SCRIBNER and Company. Letter to George Perkins Marsh, March 29, 1859, Carton 3, Folder 34, GPM, UVM.

SIMON, Sherry. Gender in Translation: Cultural Identity and the Politics of Transmission. London: Routledge, 1996.

DE STAËL, Germaine. Politics, Literature, and National Character. Translated from the French and edited by Morroe Berger. New Brunswick: Transaction Publishers, 2000.

VANCE, William L. America's Rome. 2 vols. New Haven: Yale University Press, 1989.

VOGELIUS, Christa H. “Fuller's Reproductive Originality." Society for the Study of American Women Writers, Bordeaux, France, July 2017.

VENUTI, Lawrence. The Translator's Invisibility. 1995. New York: Routledge, 2008.

\section{NOTES}

1. This essay has benefitted immensely from the feedback of anonymous reviewers for Transatlantica and participants at the Border Crossings Conference sponsored by the Society for the Study of American Women Writers and Université Bordeaux Montaigne, France, 2017.

2. I choose to employ first names to distinguish Caroline from her husband George.

3. Although unsigned and without naming George, the poem's venue and content mark it as by Caroline and about her husband.

4. Luisa Quartermaine also compares Marsh to Fuller in her time abroad, political observations and written commentary, acknowledging that Caroline's marriage to George took her life in a different direction from that of the unmarried Fuller's $(1999,61)$.

5. Both poets' collections were in the Marsh library (Catalogue, 1892 92).

6. Several notes cite French sources, such as Revue de l'Orient, rather than "originals," for her translations.

7. Caroline gave freedom to her editors to make any final decisions (August 12, 1859). It appears that they maintained her notes but eliminated the appendices, which are not in the volume.

8. Likely Marsh was unaware of this translation, or she would not have made the claim in her preface that hers was the first translation in English. 
9. I am grateful to Professor Judith E. Martin at Missouri State University for assistance with Biernatzki's text.

10. Caroline Crane Marsh, Diary, 9 November 1873. Hereafter cited within the text by date.

11. Page numbers refer to the notebooks edited by Lowenthal and Quartermaine (2004). Corresponding dates in the notebooks, available in the George Perkins Marsh collection at the University of Vermont, Carton 18, are 16 June 1861, 27 Aug. 1861, 8 Feb. 1863, and 27 March 1863.

12. 20 April 1863.

13. 27 March 1863.

14. 26 April 1863.

15. 23 April 1863.

16. Radda! Take a look but don't stop as you walk by; whoever is not a thief is a spy! Note * in original interprets the dialect "un" as "non."

17. When Brolio wants to be Brolio, all Siena trembles.

18. 23 April 1863. UVM Box 18 Vol. 14.

19. The tale also celebrates missionary preachers, whose words were like kernels of corn the villagers gobbled up, goal-setting and achieving success. I elaborate on the related journal entries elsewhere. Lowenthal also discusses Marsh's attitude toward arranged marriages (“'The Marriage of Choice"').

20. The Marsh library included writings by and about Fénelon in Channing's Works and by De Ribbe (Catalogue 222, 570). It did not include Froude's essay.

21. The Marsh library included a copy (Catalogue 35).

22. Boggs notes this volume as an example among several regional anthologies of the period (170, n. 9).

23. See letters from and to A. B. Crane in 1870,1875 and 1876 and to niece Cornelia in 1876.

24. The proposed second volume was never completed; GPM UVM holds the manuscript.

\section{ABSTRACTS}

Caroline Crane Marsh (1816-1901), wife of George Perkins Marsh, a U.S. diplomat to Turkey and Italy, deserves recognition for the ways in which her self-understanding was transformed by her travels abroad and translating practice. Caroline saw herself not only as dutiful wife or "handmaiden" to George, but also as surrogate mother, social activist, teacher, translator and aspiring author. Two volumes she translated into English, The Hallig or, the Sheepfold in the Waters: a Tale of Humble Life on the Coast of Schleswig (1856), and The Wolfe of the Knoll, and other Poems (1859), considered alongside her poetry, letters and journals, provide windows to the values of translation as a venue of negotiation and cultural exchange. Caroline's translating work emerged in a period of American exceptionalism that celebrated the Anglo as ideal subject (if not imperial colonizer) and often occluded cultural difference that had been part of the Americas since European arrival. Yet her literary labors reflect that Caroline realized her role as a mediator rather than militaristic conqueror, with translations that make difference overt and journal entries that demonstrate she recognized her limitations as a reformer and a conveyor of religious "truth." This emphasis on Caroline as translator contributes to an understudied area in discussions of American women's travel writings, building from diverse views of translation in the nineteenth century and today. 
Caroline Crane Marsh (1816-1901) mit à profit ses séjours à l'étranger (Italie et Turquie) où elle accompagnait son époux, le diplomate américain George Perkins Marsh, pour développer une pratique régulière de la traduction et, ce faisant, sa propre connaissance de soi. Caroline ne se voyait pas seulement en épouse dévouée ou simple assistante, elle se présentait comme une mère de substitution, une activiste sociale, une enseignante, une traductrice et une auteure en herbe. En regard de sa propre poésie, de sa correspondance et de ses journaux intimes, les deux œuvres qu'elle traduisit en anglais (The Hallig or, the Sheepfold in the Waters: a Tale of Humble Life on the Coast of Schleswig, 1856, et The Wolfe of the Knoll, and other Poems, 1859) permettent de mieux cerner le rôle joué par l'activité de traduction dans la négociation et l'échange culturels. Ces traductions parurent à une époque d'exceptionnalisme où l'on célébrait l'Anglo-saxon comme sujet idéal (voire comme colon impérialiste) et où la différence culturelle, pourtant indissociable de la construction des Amériques depuis l'arrivée des premiers colons, était souvent passée sous silence. Dans son travail de traductrice, Caroline met en avant son rôle de médiatrice plutôt que de conquérante militariste. Ses traductions accentuent cette notion de différence et les notes de ses journaux témoignent qu'elle avait conscience de ses limites en tant que réformatrice et détentrice d'une "vérité » religieuse. Aborder Caroline Crane Marsh comme traductrice permet donc d'éclairer certains aspects méconnus de l'expérience du voyage au féminin à la lumière de différentes conceptions de la traduction du dix-neuvième siècle à nos jours.

\section{INDEX}

Mots-clés: traduction, Caroline Crane Marsh, Italie, activisme, religion

Keywords: translation, Caroline Crane Marsh, Italy, activism, religion

\section{AUTHOR}

ETTA MADDEN

Missouri State University, ettamadden@missouristate.edu 